\title{
Construction of assistive technology as online course for the blind about hypertension
}

\author{
Construção de tecnologia assistiva na modalidade curso online para cegos sobre hipertensão arterial \\ Construcción de tecnología asistiva en la modalidad curso on-line para ciegos sobre hipertensión arterial
}

Luciana Vieira de Carvalho', Aline Tomaz de Carvalho', Aline Cruz Esmeraldo Áfio', Andréa Soares Rocha da Silva', Máguida Gomes da Silva', Lorita Marlena Freitag Pagliuca'

' Universidade Federal do Ceará. Fortaleza, Ceará, Brazil.

How to cite this article:

Carvalho LV, Carvalho AT, Áfio ACE, Silva ASR, Silva MG, Pagliuca LMF. Construction of assistive technology as online course for the blind about hypertension. Rev Bras Enferm [Internet]. 2018;71(4):1970-6.

DOI: http://dx.doi.org/10.1590/0034-7167-2017-0056

Submission: 03-10-2017_Approval: 10-16-2017

\begin{abstract}
Objective: to develop affordable education course for the blind on the prevention of hypertension. Method: we used the Model of Development of Digital Educational Materials composed by the stages of analysis and planning; modeling; implementation; evaluation and maintenance; distribution. Results: we obtained fifteen pages divided into six learning units. The study followed the accessibility standards of national and international documents. Evaluation and maintenance phase occurred during preparation of the course. Final considerations: to elaborate a course as assistive technology for the visually-impaired is a feasible task, provides knowledge about hypertension prevention and equality of access to digital educational materials.
\end{abstract}

Descriptors: Hypertension; Visually Impaired Persons; Education, Distance; Nursing; Health Promotion.

\section{RESUMO}

Objetivo: desenvolver curso de educação acessível para cegos sobre prevenção da hipertensão arterial. Método: utilizou-se Modelo de Desenvolvimento de Material Educativo Digital composto pelas fases de análise e planejamento; modelagem; implementação; avaliação e manutenção; distribuição. Resultados: obteve-se quinze páginas divididas em seis módulos didáticos. O estudo seguiu os padrões de acessibilidade dos documentos nacionais e internacionais. A fase de avaliação e manutenção ocorreu durante elaboração do curso. Considerações finais: construir curso como tecnologia assistiva para cegos é tarefa viável, oferece conhecimento sobre prevenção da hipertensão e igualdade de acesso a materiais educativos digitais.

Descritores: Hipertensão; Pessoas com Deficiência Visual; Educação a Distância; Enfermagem; Promoção da Saúde.

\section{RESUMEN}

Objetivo: desarrollar un curso de educación accesible para ciegos sobre prevención de la hipertensión arterial. Método: se utilizó Modelo de Desarrollo de Material Educativo Digital compuesto por las fases de análisis y planificación; modelado; aplicación; evaluación y mantenimiento; distribución. Resultados: se obtuvieron quince páginas divididas en seis módulos didácticos. El estudio siguió los estándares de accesibilidad de los documentos nacionales e internacionales. La fase de evaluación y mantenimiento ocurrió durante la elaboración del curso. Consideraciones finales: construir curso como tecnología asistiva para ciegos es tarea viable, ofrece conocimiento sobre prevención de la hipertensión e igualdad de acceso a materiales educativos digitales.

Descriptores: Hipertensión; Personas con Daño Visual; Educación a Distancia; Enfermería; Promoción de la Salud. 


\section{INTRODUCTION}

People with disabilities (PwD) have high representation in the population. It is estimated that there are approximately 46 million of PwD in Brazil (23.9\%), and the visual impairment has the higher prevalence in the country $(18.80 \%)^{(1)}$. Internationally, about 314 million people have vision impairments that occurred by eye diseases or not refractory error correction, of which 45 million have total blindness ${ }^{(2)}$.

This population has increased exposure to risk factors, such as physical inactivity, weight gain, inadequate nutrition, low socioeconomic conditions, difficulty of access to education and health services, which suggests information deficit. Thereby, visually-impaired individuals become more vulnerable to develop chronic diseases and need special health attention because of peculiarities inherent in their disability ${ }^{(2-3)}$.

Systemic Arterial Hypertension (SAH) outstands among the chronic diseases. It is characterized by the constant elevation of blood pressure that affects the structure and function of blood vessels and target organs such as heart, brain, eyes and kidneys. The lesions occur in the long run and are asymptomatic, causing risk of serious cardiovascular events recognized as comorbidities or complications that include peripheral vascular disease, coronary artery disease, stroke and kidney failure ${ }^{(4-5)}$.

The increasing prevalence of SAH relates mainly to the inappropriate lifestyle of the population, which provides the appearance of risk factors for the disease. Thus, the development and severity of SAH depend on the lifestyle adopted by each individual, since personal habits create risks that interfere with the quality of health. Factors inherent in the individual are also highlighted, such as genetic aspects, which contribute to the occurrence of the condition ${ }^{(5)}$.

Some of the risk factors responsible for triggering hypertension are included in modifiable category, allowing the disease to be avoided or controlled in most cases. Therefore, guiding the public about how the risk factors act in the body, as well as their impact on high blood pressure levels, contributes for people to choose healthier living habits ${ }^{(5)}$.

In view of this scenario and due to the special attention to the health of the blind, promoting preventive actions to reach this audience proved to be important. In this context, the implementation of health actions can help to meet basic demands of groups in social vulnerability ${ }^{(6)}$.

We highlight health education actions developed by professionals as strategies that enable empowerment of people in the perspective of transformation of life habits and control of health determinants ${ }^{(6)}$. In this regard, educational technologies constructed by nurses are increasing, being considered facilitators of the teaching-learning process and being used for transferring knowledge and providing participation to the individual in moment of exchange of experiences, leading to skills enhancement ${ }^{(7)}$.

Among the technologies available for the blind are Assistive Technologies (AT), characterized by resources and services that contribute to provide or expand functional skills of PwD and, consequently, promote independent living and inclusion ${ }^{(8)}$. In education, AT are relevant to the extent that allow participation of the blind in learning processes. Digital educational materials, examples of AT, are implemented through the internet. The use of this technological resource can promote inclusion of blind people in the information society.

Some guidelines are given to individuals through materials made with incompatible format to access for blind people, decreasing the possibility of this public to receive information essential to health promotion $^{(9)}$. In this case, the transfer of guidance through the internet ensure to the blind access to information in digital content, as well as meet the purpose of educational inclusion. The establishment of online teaching falls under the category of Distance Education, made possible by Virtual Learning Environments (VLES) in the form of website that can be accessed by any person, being relevant in the process of teaching and learning to the blind ${ }^{(10)}$.

In view of the considerations about social relevance of visual impairment, exposure of the blind to risk factors associated with chronic diseases, such as $\mathrm{SAH}$, and the difficulty of access to information faced by this population, to produce educational materials that contribute to health promotion of this audience is important.

\section{OBJECTIVE}

To develop assistive technology in online course for the blind about hypertension.

\section{METHOD}

\section{Ethical aspects}

This study followed the resolution no. 466/2012 and obtained approval of the National Commission of Ethics in research (Conep). All participants of the research signed the Informed Consent Form (ICF). By signing the document, we made sure to participants total anonymity and secrecy.

\section{Theoretical-methodological background}

We used the Model of Development of Digital Educational Materials composed by five stages: analysis and planning; modeling (conceptual, navigation and interface); implementation; evaluation and maintenance; distribution ${ }^{(11)}$.

\section{Type of study}

This is a methodological research on the construction of online course that includes content on clinical aspects of hypertension and preventive measures accessible to the blind.

\section{Methodological procedures}

\section{Study scenario}

To assess the accessibility of the course by the participants, were used physical space and technological equipment made available by Digital Technologies Sector of the UFC Virtual Institute, from the Federal University of Ceará (UFC).

\section{Data source}

The evaluators of the accessibility of the course were four blind people, of both genders, with average age of 18 years, who could use computer and screen readers and who could surf the internet.

The choice for this number of participants took place following the Web Accessibility Guidelines, according to which a single 
user is able to assess whether the site is accessible, however, the larger and more diverse is this number, the better the results ${ }^{(12)}$. Therefore, we opted for a total of four participants to get more suggestions about the accessibility of the technology.

\section{Data collection and organization}

The construction and evaluation of hypermedia occurred from May to November 2014. To collect data from blind participants, we used semi-structured scripts, adapted from previous study ${ }^{(13)}$, containing instructions for accessing the course. The script underwent modifications to enable users to explore the course.

\section{Study Steps}

In the analysis and planning phases, we characterized the product to be developed, delimited the theme, and chose the objectives, the target audience and the use.

In modeling, we established the structure of the material in an organized and attractive way. It covers three models, namely: conceptual, navigation and interface. In the conceptual model were determined content and complementary media and how the technology will be made available to the user through the elaboration of the script. In the navigation model, were established the structures for accessing the course and the elements that interconnect topics of the contents, for example, menus and indexes. In the interface model, the visual identity of the technology was defined; we highlight that, in our study, visual and sound representations were designed as universal design concept, making them accessible to the target audience.

In implementation, the course is hosted in specific programs to assess consistency between pages, links, visual elements, audio and to verify whether offers accessibility conditions to the target audience, which allows to correct inconsistencies.

Evaluation and maintenance phase occurred during the preparation of the course. Note that the content of the course was not submitted to experts for evaluation, since it was adapted from reliable scientific literature, produced by national health authorities.

The distribution will be addressed in future study, as it refers to the final implementation of the material in the execution device, i.e., on the internet, so that users can use it.

\section{Data analysis}

For developing the online course accessible to the blind, we followed the accessibility guidelines of the international document Web Content Accessibility Guidelines (WCAG), version $2.0^{(14)}$ and of the national, named Model of Accessibility of the Electronic Government (e-MAG), version 3.0 $0^{(12)}$.

In assessing the accessibility of the course for the blind, were noted the participants' perceptions during navigation by the educational material, with further analysis to implement possible suggestions for improving the course.

\section{RESULTS}

\section{Analysis and planning}

There is evidence that blind people present high vulnerability for developing chronic diseases ${ }^{(2-3)}$, thus the need for constructing the educational technology entitled "Hypertension: learn how to prevent it".
The choice of the objectives includes the construction of accessible technology about hypertension, whose aim is to encourage the prevention of this pathology by the blind population. As for the audience, technology was constructed as educational resource for blind people aged from 18 years. The inclusion of this age group was to encourage the access of young people to the hypermedia content, encouraging early participation in health care. We highlight that the course has adaptations that make it accessible to the blind population, but that will not prevent the use by people without vision impairment.

For accessing the course, we chose the VLE called Online Learning System (Solar) of the UFC because of its interactive space, whose aim is to offer environment for publication of courses in distance mode to teachers and students.

\section{Modeling}

In the conceptual model, we selected the content of the course by searching scientific literature on the subject, in order to include reliable and updated information. Literature review was carried out in reliable references from national bodies that discuss the subject. These materials were adapted regarding information relevant to the prevention of information on $\mathrm{SAH}$ and simplification of vocabulary for reading to become understandable to users. After constructing the content, the script was elaborated in storyboard to organize texts, multimedia (images, audios, tutorials for accessing Solar and further reading files) and forums.

In the navigation model, a Web Designer constructed the pages of the course in particular serve from the storyboards, in Hypertext Markup Language format (HTML). Menus, links, text boxes, and audio description for image interpretation were defined. Two images were inserted in the scope of the content of the course, which refer to the logo and illustration of blood vessel with blood, showing blood pressure exerted within the wall of this vase.

The logo was developed to demonstrate that the course is accessible to the target audience (blind and sighted), encompassing from young population to the elderly, and to emphasize the theme addressed, i.e., arterial hypertension. Thus, the final design has two characters: a young blind man who uses accessories like glasses and cane, and a sighted old lady. Between them, there is an image of heart representative of hypertension. A text box was inserted in the logo for describing the elements that compose it. Such a feature was also placed in the link that directs the student to the tutorials of the Solar, facilitating its location and interpretation.

Regarding the blood vessel image, it was placed an audio description resource corresponding to the characteristics of that image. For this, an explanatory text was elaborated, and an audio-recording of the content was made, thus generating file in Mp4 format with duration of 24 seconds. When inserted in the HTML code, this file originated audio track player, being attached below the image.

Were defined background color, color and size of the letters, size of images and logo of the course, components of the interface model phase, which determines the visual identity of the technology. Thus, the appearance is attractive to the public. 
Were constructed fifteen HTML pages, divided into six learning units entitled: Presentation; Class 1 (Introduction to the use of the Solar environment); Class 2 (Learning about hypertension); Class 3 (Blood pressure measurement); Class 4 (How hypertension is acquired) and Class 5 (How to prevent hypertension). Note that classes 2 to 5 have activities forums, characterized as asynchronous: Forum Class 2 (discuss the consequences of high blood pressure in the body); Forum Class 3 (Chat with colleagues about the care that you adopt with the blood pressure measurement); Forum Class 4 (think about the factors that cause hypertension. Your lifestyle is suitable for maintaining good health?); and Forum Class 5 (discuss the measures we should adopt to prevent hypertension).

\section{Implementation}

Note that e-MAG recommends that the accessibility test must initially be run through automatic evaluators (software), with subsequent manual evaluation by users. This procedure enables detection of accessibility problems effectively ${ }^{(12)}$.

Fifteen pages of HTML were implemented in particular serve to evaluate access to pages, links, visual and audio elements, through software called Site Accessibility Evaluator and Simulator (Ases). Before the error report provided by Ases, inappropriate sites were identified, which suffered modifications to become accessible. After this procedure, we found that such elements were operable, appropriately arranged and offered conditions for access to the blind. This process took place with the aid of the webdesigner. Then, the course was hosted in the Solar environment, and four blind people performed the evaluation of accessibility. Note that the choice of four participants occurred as suggestions of e-MAG. The document states that a single user is able to evaluate the site and report if it is accessible or not. Participants performed sequential navigation activities by the course proposed in the semistructural scrip, accessed the content class and reported that the components (text, links, images, audio) were accessible. After analysis of the perceptions of blind people, we found that the course does not require modifications regarding accessibility.

\section{Evaluation and maintenance}

The course evaluation process took place along the phases of preparation, being essential to participation of professionals from different areas of expertise (health professionals, responsible for the study in question, and a web designer), in addition to the blind users by enabling improvements in the quality of technology, especially in terms of accessibility, due to the various approaches of the opinions offered.

\section{DISCUSSION}

The dimension of this research is considered to be complex because the course was constructed to satisfy physical, social, cultural, technological and educational aspects of the blind population. To complete the course, it was necessary to perform in-depth analysis of the literature aiming to investigate and understand the best conditions for provision of the content, linking all these elements. Regarding the physical aspect, the hearing was considered for information processing due to the change of visual function. In the fulfillment of the social aspect, we sought to promote interactivity with other people through the forum. In the cultural aspect, we respected the history of the blind person in society and how it was reflected in the conditions of access to health information. Concerning educational aspects, we opt for distance learning course, hosted at AVA, with dynamic and accessible content. In the technological axis, were considered the resources most used by blind people to search for information, with an emphasis on computer with screen reader and internet.

The challenge of constructing the course "Hypertension: learn how to prevent it" arose from the perspective of providing new experiences in the teaching-learning process for blind people. The course proposes to stimulate interest in the subject of hypertension and preventive measures by offering didactic modules structured in a dynamic, attractive, organized and effective way, contemplating the accessibility criteria to enable that the blind have autonomy when using it and enjoy adequate means for obtaining new knowledge on health. We opted for distance learning course, implemented in the AVA Solar created by the UFC.

When considering the vulnerability of blind people to develop hypertension, to provide more opportunities for this audience to know accessible educational materials, with theoretical foundation on the topic, allows the formation of new knowledge, reflections on the life style adopted and, consequently, health promotion.

For the blind, the internet is essential for personal and professional growth. Many take advantage of this tool and through it reach spaces considered unreachable before. Through the internet, advances occur in several areas, including in education. It is in this sense that health promotion of blind people can be reached using the technological means for transfer of information ${ }^{(10)}$.

Through the educational process, nurses stimulate healthy habits. As an educator in health, he/she needs to use appropriate communication to provide information efficiently, contributing to the understanding of the participant. Thereby, the communicative process becomes an essential tool to stimulate health maintenance ${ }^{(15)}$. Thus, to carry out health education to blind people through educational materials adapted to this audience, characterized as AT, it is essential that nurses know the particularities of this population to provide educational moment conducive to meeting their real needs through innovative educational technologies that encourage health promotion.

It is important to report that nurses constantly carry out research involving PwD and, thus, they enhance the knowledge about the characteristics and needs of this population, including the blind. Corroborates this statement a study which involved the construction of AT to be used in educational activities with the blind, entitled Online Course on Breast Health ${ }^{(13)}$. The results of this study showed that the educational material developed contributes to improve the knowledge of the blind person on the subject addressed, becoming important strategy used by health professionals, especially nurses, for health promotion of the blind.

In this context, public policies target at PwD highlight the importance of developing educational materials aimed at improving the quality of life of this group. They offer to the blind people greater opportunity to access educational practices, since among its guidelines is the improvement of the healthcare professional to attend this public in an appropriate manner, 
as well as stimulate the production of accessible educational materials, such as educational guidance through audio, textures, among others ${ }^{(16)}$.

When it comes to blind people, the development of course offered on the internet involves greater concern, given that these people do not have the same visual experiences of sighted people. Therefore, the acute presence of senses of hearing and touch is highlighted, which make possible to construct the mental representation of the material exposed. In that way the blind population participates in educational activities with success. However, we cannot forget that to obtain a satisfactory result, that is, the largest number of people with and without disabilities, we must respect the principles of universal design during the construction of digital educational materials ${ }^{(13)}$.

These materials are tools that enable distance learning, allow the users to perform dynamic interactions with the content and explore it in their pace, which facilitates the construction of knowledge ${ }^{(11)}$. In the case of a course offered on the internet, it is necessary to contemplate the issues of accessibility for digital sites recommended by national (e-MAG) and international (WCAG) bodies, in order to be adapted to the use of the target population.

Guidelines of the e-MAG recommend that, in internet pages, links must be listed, not be juxtaposed or, when they are present in the middle of the text, must be signaled by commas or parentheses ${ }^{(12)}$. The correct disposal of the links on the pages is an important factor to facilitate navigation for blind people. Links organized and signaled avoid loss of content by the blind. However, when they are not disposed properly, they become barriers to accessibility.

To navigate in digital environments can become a challenging process for the blind, whether the content available is not properly structured or there is incorrect presence of links between pages. Compliance with this recommendation by the web designer certainly contributed to reduce browsability. Thereby, in the online course we opted for introducing simple pages, content with clear language, divided into short paragraphs and listed. The links have the same characteristics, being signaled with short texts and organized into logical sequence to permit fluidity in content and between pages.

In relation to the WCAG document, it is recommended to provide different forms of navigation for content to the users, to facilitate their positioning on the page $\mathrm{e}^{(14)}$. Thus, in the course "Hypertension: learn how to prevent it" header topic was implemented with the title of each class to identify the beginning of pages, links at the end of these, indicating the end of the content with the options "back" and "next", among other resources.

It is relevant to the blind reader the correct identification of the images present in the technology, since they contribute to full access to the information, allow greater understanding of the content and interactivity while browsing. The e-MAG document recommends providing appropriate texts as an alternative for viewing the images on the site, making them accessible. It must be inserted in any image present on the page a short description of its content, with textual equivalent that detail its features correctly so that the user adapt it to the rest of the context and be able to identify such elements ${ }^{(12)}$.

Note that a faithful description of the images through text boxes was inserted in the course, exemplified by the logo image and link to access the video tutorials of the Solar. The audio description was inserted in the figure that illustrates the blood pressure exerted by the blood when colliding in the blood vessel wall, describing in detail this process.

The audio description allows the digital inclusion of people with visual impairment. It consists in accessibility resource that aims to make theatre, cinema, TV and art works accessible to blind people. It is additional narration that describes actions, body language, facial expressions, sets and costumes, ensuring accessibility to visual information to individuals with visual impairment ${ }^{(17)}$. By describing images using simple and short text, we can promote the learning of blinded and sighted ${ }^{(18)}$.

The Forum tool has function of interactivity, a means for exchange of information and experiences between participants, strengthening learning. The course in online mode for blind women composed of five teaching units employed asynchronous forums in three classes, which encourages discussions among participants on issues relating to breast health ${ }^{(13)}$.

Nursing uses, in any environment, technologies as a strategy for stimulating the assistance and promoting the autonomous and independent being. As well as nurses, professionals working in other areas also have technologies to empower the clients assisted ${ }^{(9)}$.

The process of construction of the AT "Hypertension: Learn how to prevent it" involved several areas of expertise, such as nurses and computer professional, in addition to the contribution of blind people, target audience to which the technology is aimed at. At present, as accessibility issues are gaining importance in society, professionals who have theoretical and practical grounds in the development of technologies work as a team, each one in a specialty, to help in the improvement of materials that provide opportunity to learn, autonomy and independence to the PwD. This fact reinforces the importance of intersectoral approach in health, characterized by the completion of the services, in which the improvement of the quality of life of individuals is established by co-management ${ }^{(19)}$.

By effort of the people involved in the construction of the course, we can observe a feeling of struggle for equal rights. Throughout history, the PwD had limited opportunities to participate in activities related to the improvement of the quality of life and health. Therefore, the development of accessible educational technologies, as this course, is one of the means to respect the rights of PwD to education, social inclusion, and to promote access to health actions, by allowing these people to enjoy adapted materials that contribute to enhance the knowledge about health. As AT that seeks to promote the health of blind people, providing quality of life and inclusion, the course was developed to offer equal opportunities for this population.

\section{Study limitation}

As limitation of this study, we highlight that there was difficulty in locating blind people who accepted to participate in the research. Personal issues or difficulty to get to the place of the evaluative process prevented the adhesion. This fact did not limit the validity of the study, once were met the recommendations of documents that deal with web accessibility guidelines as to the number of subjects needed to evaluate the access to the technology. 
Contributions to the field of nursing, health, or public policies

This report aims to encourage nurses and future nursing professionals to develop accessible educational materials to provide sources of innovative health guidelines to the blind, based on individual learning in a dynamic, interactive and effective manner.

\section{FINAL CONSIDERATIONS}

A AT was constructed, characterized by course accessible to blind people about prevention of SAH. Due to the current context of significant need for digital inclusion of this audience, it was decided to develop a distance learning course, which was made available in the Virtual Learning Environments VLE Solar.
The course was structured through accessibility criteria recommended by national and international bodies. Fifteen HTML pages were constructed, divided into six learning units We found that the construction of accessible educational materials is a complex task, which involves approach with issues of accessibility of digital materials, but it is not unreachable, and allow us to offer technologies that enable social and digital inclusion of blind people.

The construction of the course is completed. Therefore, it is among the practical implications the possibilities to use the AT as a tool for promoting health, helping blind people to learn about SAH to encourage the adoption of healthy habits for preventing this disease. By being made available on the internet, it can be employed in educational strategies and, due to its accessible character, will assist on social and digital inclusion of the target audience.

\section{REFERENCES}

1. Brasil. Instituto Brasileiro de Geografia e Estatística. IBGE. Cartilha do Censo 2010: pessoas com deficiência [Internet]. 2012[cited 2016 Dec 10]. Available from: http://www.pessoacomdeficiencia.gov.br/app/sites/default/files/publicacoes/cartilha-censo-2010pessoas-com-deficienciareduzido.pdf

2. Governo do Estado de São Paulo. Secretaria dos Direitos da Pessoa com Deficiência. Sumário Relatório Mundial Sobre a Deficiência[Internet]. 2012[cited 2017 Mar 08]. Available from: http://apps.who.int/iris/bitstream/10665/70670/9/WHO_NMH_ VIP_11.01_por.pdf

3. Seron BB, Interdonato BB, Luiz Jr GC, Greguol M. Prática de atividade física habitual entre adolescentes com deficiência visual. Rev Bras Educ Fís Esporte [Internet]. 2012[cited 2016 Dec 10];26(2):231-39. Available from: http://www.scielo.br/pdf/rbefe/v26n2/06.pdf

4. Malachias MVB, Souza WKSB, Plavnik FL, Rodrigues CIS, Brandão AA, Neves MFT, et al. $7^{a}$ Diretriz Brasileira de Hipertensão Arterial. Arq Bras Cardiol [Internet]. 2016[cited 2017 Mar 08];107(Supl 3):1-83. Available from: http://www.scielo.br/pdf/abc/ v107n3s3/0066-782X-abc-107-03-s3-0067.pdf

5. Machado MC, Pires CGS, Lobão WM. Concepções dos hipertensos sobre os fatores de risco para a doença. Ciênc Saúde Colet [Internet]. 2012[cited 2016 Dec 13];17(5):1357-63. Available from: http://www.scielo.br/pdf/csc/v17n5/a30v17n5.pdf

6. Lopes RE, Malfitano AP, Serrata PA, Furlan FG, Brito EM. Educação e saúde: territórios de responsabilidade, comunidade e demandas sociais. Rev Bras Educ Med [Internet]. 2012 [cited 2016 Dec 13];36(1):434-40. Available from: http://www.scielo.br/ $\mathrm{pdf} / \mathrm{rbem} / \mathrm{v} 36 \mathrm{n} 1 \mathrm{~s} 1 / \mathrm{v} 36 \mathrm{n} 1 \mathrm{~s} 1 \mathrm{a} 03 . \mathrm{pdf}$

7. Barros EJL, Santos SSC, Gomes GC, Erdmann AL. Educational geronto-technology for ostomized seniors from a complexity perspective. Rev Gaúcha Enferm[Internet]. 2012[cited 2016 Dec 13];33(2):95-101. Available from: http://www.scielo.br/pdf/rgenf/v33n2/14.pdf

8. Bersch R. Introdução à tecnologia assistiva [Internet]. 2014[cited 2016 Oct 15]. Available from: http://www.assistiva.com.br/ Introducao_Tecnologia_Assistiva.pdf

9. Mariano MR, Rebouças CBA, Pagliuca LMF. Educative game on drugs for blind individuals: development and assessment. Rev Esc Enferm USP[Internet]. 2013 [cited 2016 Oct 08];47(4):930-36. Available from: http://www.scielo.br/pdf/reeusp/v47n4/en_00806234-reeusp-47-4-0930.pdf

10. Freitas LV, Teles LMR, Lima TM, Vieira NFC, Barbosa RCM, Pinheiro AKB, et al. Physical examination during prenatal care: construction and validation of educational hypermedia for nursing. Acta Paul Enferm[Internet]. 2012[cited 2016 Dec 13];25(4):5818. Available from: http://www.scielo.br/pdf/ape/v25n4/en_16.pdf

11. Falkembach GAM. Concepção e desenvolvimento de material educativo digital: novas tecnologias na educação Renote[Internet]. 2005[cited 2016 Dec 13];3(1):1-15. Available from: http://seer.ufrgs.br/renote/article/view/13742/7970

12. Brasil. Ministério do Planejamento, Orçamento e Gestão. Secretaria de Logística e Tecnologia da Informação, Departamento de Governo Eletrônico. e-MAG - Modelo de Acessibilidade em Governo Eletrônico. Brasília: Ministério do Planejamento, Orçamento e Gestão; 2011.

13. Carvalho AT, Pagliuca LMF, Fernandes AFC. Breast health to blind woman: validation of accessible online course. Adv Internet Things [Internet]. 2015[cited 2016 Dec 15];5:7-14. Available from: http://file.scirp.org/pdf/AIT_2015010716132415.pdf

14. Web Content Accessibility Guidelines-WCAG-2.0 [Internet]. 2014 [cited 2016 Nov 15]. Available from: http://www.w3.org/ Translations/WCAG20-pt-PT/WCAG20-pt-PT-20141024/

15. Coriolano-Marinus M WL, Pavan MI, Lima LS, Bettencourt ARC. Validation of educational material for hospital discharge of patients with prolonged domiciliary oxygen prescription. Esc Anna Nery Rev Enferm[Internet]. 2014[cited 2017 Mar 08];18(2):284-9. 
Available from: http://www.scielo.br/pdf/ean/v18n2/en_1414-8145-ean-18-02-0284.pdf

16. Brasil. Ministério da Saúde. Política nacional de saúde da pessoa portadora de deficiência. Brasília: Ministério da Saúde; 2010.

17. Alves SF, Araújo VLS. Formação do audiodescritor: a estética cinematográfica como base para o aprendizado da estética da audiodescrição. Materiais, métodos e produtos. Cad Trad [Internet]. 2016[cited 2017 Mar 08];36(3):34-59. Available from: http:// www.scielo.br/pdf/ct/v36n3/2175-7968-ct-36-3-0034.pdf

18. Guercio A, Stirbens KA, Williams J, Haiber C. Addressing challenges in web accessibility for the blind and visually impaired. Int J Dist Educ Technol [Internet]. 2011[cited 2016 Dec 13];9(4):1-13. Available from: http://www.igi-global.com/article/ addressing-challenges-web-accessibility-blind/58983

19. Cavalcanti AD, Cordeiro JC. As ações intersetoriais na Estratégia de Saúde da Família: um estudo da representação do conceito de saúde e de suas práticas na Atenção Básica. Rev Bras Med Fam Comunidade [Internet]. 2015[cited 2017 Mar 08];10(37)1-9. Available from: https://www.rbmfc.org.br/rbmfc/article/view/1059/744 